\title{
The Improvement of Children's Social Emotional Achievement Through the Implementation of Traditional Games (An Action Research in Early Childhood Education (PAUD) Mutiara Hati Mataram 2015)
}

\author{
Istati Dwi Rahayu
}

Early Childhood Department, University of Mataram, Mataram, Indonesia, dwiistati@unram.ac.id

\begin{abstract}
The research aims to improve the children's social emotionalachievement through traditional games. The traditional games are the solution for the existing cultural and untapped potential for the stimulation process in early childhood. The experiment was conducted among 16 children of group B of Early Childhood Education Mutiara Hati Mataram in 2015. The action research was done through the four items, namely planning, action, observation, and reflection conducted on three cycles. The process of the data collection was done through interviews, observation and document analysis and were interpreted using quantitative and qualitative analysis. The criteria of achievement research agreement was $75 \%$ in the classical style. The research results indicatedthat the games can improve the children of 5-6 years social emotional achievement. In the pre-cycle of the children's social emotional lower was Children aged 5-6 years achieved at 36.57\%, however, after the experiment conducted, the improvement Achieved are from 52.93\% in cycle 1, 70.32\% in cycle 2, and $82.92 \%$ in the cycle 3. The traditional games of 'kemantenan' and 'Pucia-cia' can be more dominant increase of children emotions and empathy, while 'lung-lung se' and 'begang meow' can be more dominant to improve the relationship and cooperation aspects.
\end{abstract}

\section{Keywords: Social Emotional achievement, Traditional Games, Children aged 5-6 years.}

\section{INTRODUCTION}

One of the very important ability to be developed in early childhood is the social emotional. Social emotional can be translated into the ability to manage emotions and social skills. Both are abilities that are interrelated and influence each other.

Debriefing and provision of appropriate stimulation on social emotional of early childhood, hopefully make them be able to cope with the various problems that arise during the process of social development in the their golden age. At this time the child is directed to have emotional balance needed in life, especially in social life now and later.

Based on observations and interviews with educators from NTB (formal and informal), game tools that they have is very limited and also limited teacher finally, early childhood education be implemented as formal education in elementary school, teachers teach children in classical and children are forced to hold a pencil and paper to learn to write, read and count. This makes these children lose the opportunity to enjoy childhood is supposed to be filled with play, joyous and free to do what they desire to know about world around them. Whereas in early childhood education, the developmental needs of children should be done with the approach of learning through play.

Low social emotional child in the city of Mataram, caused by the limited educative equipment and learning strategies that are not child-centered. The same thing also happened in early childhood MutiaraHatiMataram. Symptoms that appear is including the child is not able to share learning equipment, such as scrambling using colored pencils particular when conducting coloring, it is difficult to stand in line when doing activities such as washing hands, line up, shake hands with the teachers, or out of the classroom when it will break or go home. Other symptoms also appeared in more than $50 \%$ of children have not been able to express negative emotions in a manner consistent with the norms, that is by hitting or cursing with harsh words or word is not good. The cooperation child barely visible, because children almost never facilitated by activities that require cooperation. Based on the above symptoms then the question that arises is how to develop social skills emotional children aged 5-6 years.

According to Patria (in the Proceedings of the 3rd International Conference of Early Childhood Education 
(ICECE) 2015), traditional games can sharpen a child's social emotional skills, cooperation between friends, and high sportsmanship spirit to admit defeat. Through traditional games, children can get to know the various aspects of social or norms of social life, and also can control the feelings and thought to stimuli from outside and within the individual.

Emotions are feelings that arise when a person in a state or an interaction which is important to him. The emotional development of a child has a characteristic, namely a strong reaction memikiki individualized, punishment evoke emotions is learning how to adjust to the environment. Emotion is one form of communication for the child's emotional.If the child is able to adapt to their social environment, means that he was able to regulate their emotions more effectively, and can make connections with others. Meanwhile social development is the ability to behave in accordance with social demands, or in accordance with the norms, values or social expectations.

The ability to manage the emotions of children is not independent and can not be separated from social skills. Social behavior is a real measurement of the ability of emotions, otherwise the ability of emotion can only be seen if the dug through social behavior and lives of children. Adults also can assess the child's emotional and social development and the kind of dominant form of what appears and is shown by the children in the association and its activities.

Erikson's psychosocial development of children restrict the range of 3-6 years who were at the time of initiative versus guilt (in Crain, William, 2010). At this time the child trying to explore various ways to have acts of initiative, make a plan, set goals, and have the spirit to achieve acceptable social environment, especially peers. If it succeeds or fails or is received, then the feelings of guilt would have been avoided. Guilt usually arises when the child assesses his behavior as a failure (Lewis, 2002 in Santrock, 2007). Children are more likely to actively engage in physical play with their peers and to show the positive influence while doing so. They also tend to be flexible in the game they did, meaning that they are willing to deviate from the role while playing in progress (Hughes, F Fergus, 2010).

In line with that Vygotsky found to achieve higher growth, the child can not be separated from social and cultural activities. Developing social skills as interaction with the social environment, especially the interaction between children and parents, teachers, and peers. Social context includes a variety of situations, events, social environmental response is received and processed by the child an experience of learning experiences in early life is a period of formation. Factors affecting social skills, among others, is an opportunity, motivation, meaningful communication, and identification.

For early childhood stimulation of social emotional abilities can best be done through playing. Play can reduce tension, sadness, and can learn to solve problems. With a chilcan explore, experiment, imitation (imitation and adaptation). And when the play is the child can indicate the level of social acceptance.

Programs of social intervention that can be applied in order to train social skills of children in group play is divided into three categories/stages modeling gives an example, coaching/training and shaping/forming (Ladd, Herald, Andrews 2006, in Hughes, F Fergus, 2010). Modeling program utilizes video of adults or other children who are members of a social situation. Training/coaching involves giving certain instructions in people skills, the ability to interact spontaneously, and then providing feedback/feedback informing children about their success when using these skills. Shaping/formation involves giving praise to children who have demonstrated the skills that have been taught. Of the three stages, training is the most effective.

The game is a means to engage in play. Saalah one form of the game is a traditional game, which is inherited from generation to generation. As one of the cultural heritage, and traditional games has its advantages and benefits, among others, is not require a fee to play, train children's creativity, develop social intelligence and emotional child, bring children to nature, as a medium of learning values, develop child motor skills, beneficial to health, optimizing the child's cognitive ability, gives happiness and joy, can be played across ages and hone the art sensibilities of children.

\section{RESEARCH METHODOLOGY}

The experiment was conducted in group B PAUD MutiaraHatiMataram with the number of children 16 (9 women 7 men). The research method was action research through three cycles consisting of four phases, namely planning, action, observation, and reflection. The process of data collection is done through interview, observation and document analysis, and quantitative and qualitative were analyzed. Completeness criteria was $75 \%$ of children are reaching the $75 \%$ attainment of social emotional development.

Instruments social emotional abilities of children is a derived from the four (4) aspects, namely (1) managing emotions; (2) empathy; (3) relationships; (4) cooperation.

\section{RESULT AND DISCUSSION}

Observations on social emotional abilities that take place prior to the intervention resulted in the following data: against children using instruments that have been developed. Berdasarkan that they observed data showed social emotional abilities of children as follows: 1) manage the emotions of $39 \%$; 2) Sympathy $34 \%$; 3) relationships $41 \%$; and the cooperation of $33 \%$.

Low children's ability to manage emotions more dominant demonstrated by the attitude that is not within the rules. While the low empathy through not willing to listen to others speak. Lack of cooperation shown by the reluctance to participate in group games and completing tasks together in a group. Through the results portrayed on pre-intervention study, the researcher collaborators concluded that need to be applied as an alternative to 
traditional games or activities to develop social emotional abilities of children.

The traditional games are applied in cycle 1 is Puciacia and kemantenan, a total of 6 meetings. Results of observation for the implementation of the application of traditional games in cycle 1 produces social emotional data as follows:1) managing emotions $57 \%$; 2) Sympathy $54 \%$; 3) relationships 46\%; and the cooperation of $53 \%$. Indicator managing emotionsmay increase, but the attitude that does not fit the rules are still the dominant visible. Achievement of listening to other people still do not seem to be good. Likewise, the child is still difficult to give encouragement to a friend at the time of the game. Increased cooperation with friends in completing tasks in the group is still not encouraging.

Based on discussions with collaborators, weakness in cycle 1, among others are playing the opener in the form of gymnastics that make the children become bored, coaching and mentoring during the process of play need to be improved, it needs traditional game a lot of challenges. While the strength is happiness when children playPuciacia (sandbox), because there is the challenge of winning or losing.

Based on discussions with collaborators things that need to be corrected based on the reflection cycle 1 is: Traditional game is done to replace gymnastics during play opener before entering the classroom, traditional games are more fun and more challenging, and more provide the opportunity to interact, process guidance and assistance in the process of playing is still very necessary.

The traditional games are applied to the second cycle is the lung-lung and mew begang se, as much as 6 meetings. Results of observation for the implementation of the application of traditional games in cycle 2 resulted in social emotional data as follows:1) managing emotions $69 \%$; 2) Sympathy 67\%; 3) relationships $74 \%$; and the cooperation of $69 \%$. The achievement of each indicator on aspects of managing emotions and aspects of relationship nothing flashy. Indicators with the lowest achievement for aspects of empathy ishave positive feelings about yourself. Children are also still difficult to carry out cooperation within the group, although there has been improvement compared to the first cycle.

Some aspects that need to be corrected based on the reflection cycle 2 is appropriate traditional game is selected to enhance the child's social emotional, so the game can be continued for the next cycle, the location of playing children needed a bigger place, because in the process of playing, especially playing meow begang children running around chasing each other.

The traditional games are applied in cycle 3 is the fourth game that has been applied in cycle 1 and 2, with 5 meetings. The results of observations of 3 cycles produce social emotional data as follows:1) managing emotions $82 \%$; 2) Sympathy $81 \%$; 3) relationships $86 \%$; and the cooperation of $82 \%$.

Theoretical construction which can be found on the pattern that is likely to occur can be identified and described as follows: 1) Early childhood more likely to actively engage in physical play with her friends and to show the positive influence while doing so; 2) requires the ability to choose a traditional game in accordance with the objectives and themes taken; 3 ) Traditional games can be modified according to the ability of the child; 4) silabus are arranged to accommodate the traditional game; 5) A turndown and game tools adapted to the game selected; 6) Step-by-step implementation tradisisonal games for kindergarten children to follow the stages of Preparation, Modeling, Coaching, shaping; 7) Mentoring teachers also serves to evaluate and stimulate; 8) The social aspect of emotional child can develop naturally and spontaneously in conjunction with the ongoing traditional games are fun for children. Eighth these conclusions be a reinforcement of the quantitative findings represent an early emergence of social emotional abilities of children aged 5-6 years.

Conceptually theoretical research has found and formulated the theory construction, namely how the application of traditional games in early childhoodAnd how social emotional development happens to them. In essence, children learn through play, and therefore learning in early childhood is basically a play. In accordance with the characteristics of early childhood, which are active in a variety of exploration on the environment, then the play activities are part of the learning process.

The dominant emotion management shown by the child during the process of applying the traditional game is the child shows a cheerful attitude, it can show a more positive attitude in the face of angry and difficult, and can show their responsibility in the task or role playing games in hand. Through traditional games of this indicator may be adjusted to meet the success criteria. This is in accordance with the opinion Freud and Ericson, that play helps children master the anxiety and conflict, because the tension slacken in the game, so that the child can face the problems of life (in Santrock, John W, 2007). That view illustrates the emotions going and growing in a social situation in which children interact. When interacting with the social environment, children begin to build awareness of their existence and how the environment showed a response to its existence. Child interactions that occur normally is through play. In playing, children explore, experiment, imitation (imitation) and adjustment or adaptation to the social environment. This process as well as the reinforcement that the child can build initiatives attitudes and behaviors when interacting both with teachers and with peers (peergroup).

Kethics interact intensely in the game, children also got the opportunity to show their appreciation for his opinions and views, show attention and affection, helping friends and show patience in waiting. It is more dominant shown when in small groups of 3-5 children. That was done by a child while discussing and applying ideas in play. These indicators are more dominant shown children in cycle 1, with the intervention of applying traditional game Pucia-cia and kemantenan. The game's characters, among others, are located in a small group, more dominant develop fine motor skills and creativity.

The cycle 2, traditional games that are applied are lung-lung se and mew begang. The game character is more 
on the development of gross motor skills or physical game, are in a large group, and set up a strategy to win the game. In the execution of the game application shows that communication within the meaning of greeting, watching other children play, giving encouragement to a friendoccurs spontaneously, without the need to be stimulated. This encourages children to move to play and work together to solve problems in the group. Children are more likely to actively engage in physical play with their peers and to show a positive effect on aspects of cooperation during a game.

This positive influence will have a tendency to stick and internalize if conducted socialization through fun games continuously. This is in line with the opinion of Hurlock stating that the patterns of behavior in social situations in early childhood among others cooperation, children learn to cooperate with his friends. More and more opportunities to work together, they will more quickly learn and apply them in real life. Children learn how to negotiate, resolve conflicts, menyelesaaikan problems, get along with each other, take a turn, be patient, work together, and sharing.

In this traditional game children learn abide by the rules and do with friendship, and playing with the structure and specific rules. Play encourages children to make the rules that govern their interactions, as well as stimulate them to focus on the meaning of their social interaction. Children are more likely to actively engage in physical play with their peers and to show the positive influence while doing so. They also tend to be flexible in the game they did, to switch roles being played. Thusberarti that the role of an adult or teacher needed for the game, to remain ready to provide the appropriate stimulation to the child's abilities, and ready to modify the game to keep them fresh and still provide a challenge.

This study shows that the game kemantenan and Pucia-cia who have the criteria to play in small groups and stimulate the motoric dominant smoother than the rough motoric can stimulate aspects of managing emotions and empathy is greater than the relationship and cooperation. While the traditional game-lung lung seand mew begang characterized by gross motor games, develop a strategy to win the game, a large group (10 - 15 people), play outside the classroom can improve social skills greater emotional in relationships and cooperation aspects.

From the above it can be suggested that in order to enhance the social emotional skills, children should be given ample opportunity to play fun, which is done in groups and receive guidance from adults.

The process of implementing a traditional game has given the changes to the social skills of children 5-6 years emosonal in ECD MutiaraHatiMataram 2015. Steps for the application of the traditional game is done through the stages of Preparation, modeling (Give examples), Coaching (training) and Shaping (form).

\section{REFERENCES}

[1] Achroni, Keen, 2012, Mengoptimalkan Tumbuh Kembang Anak melalui Permainan Tradisional, Yogjakarta, Javalitera.

[2] Beaty J. Janice, 2013, Observing Development of the Young Child (terjemahan Observasi Perkembangan Anak Usia Dini oleh Arif Rakhman) Jakarta, Prenadamedia.

[3] Diane E Papalia, Sally Wendkos Old, Ruth Duskin Feldman, (2010), Human Development (terjemahan Psikologi Perkembangan oleh A.K. Anwar), Edisi 9 cetakan 2, Jakarta, Kencana.

[4] Hughes, F Fergus, 2010, Children, Play, and Development, 4nd ed., Sage Publications Inc, USA.

[5] Hurlock, B Elizabeth. (1997). Child Development $6^{\text {th }}$ Ed. (terjemahan Perkembangan Anak oleh Meitasari Tjandrasa, dkk) Penerbit Erlangga, Jakarta.

[6] Mutiah, Diana, 2010. Psikologi Bermain Anak Usia Dini. Kencana Prenada Media Grup, Jakarta.

[7] Santrock, W John, 2007, Child Development, $11^{\text {th }}$ ed., (terjemahan Perkembangan Anak, jilid 2, oleh Mila Rachmawati), Penerbit Erlangga, Jakarta.

[8] SaroinsongWulan Patria, 2015, TGMF (tradisional Game of Modification Fortress) on Social Emotional Ability, Proceeding, the $3^{\text {rd }}$ International Conference of Early Childhood education (ICECE) 2015, Early Childhood Holistic and Integrative, Faculty of Education, State University of Padang.

[9] Yusuf, Syamsu, 1.N. (2000). Psikologi Perkembangan Anak dan Remaja. Bandung: Remaja Rosda Karya. 